\begin{tabular}{|ccc|}
\hline JURNAL & Jurnal Inovasi Teknologi Pendidikan & P T | \\
INOVASI & Volume 3, No 1, April 2016 (1-12) & I lkatan Profesi Teknologi \\
PENDIDGII & Online: http://journal.uny.ac.id/index.php/jitp & Pendidikan Indonesia \\
\hline \hline
\end{tabular}

\title{
PELEMBAGAAN WEB-BASED LEARNING PADA JURUSAN KURIKULUM DAN TEKNOLOGI PENDIDIKA FAKULTAS ILMU PENDIDIKAN UNIVERSITAS NEGERI JAKARTA
}

\author{
Eveline Siregar \\ evelinesiregar@gmail.com
}

Program Studi Teknologi Pendidikan Fakultas Ilmu Pendidikan Universitas Negeri Jakarta

\begin{abstract}
Abstrak
Penelitian ini bertujuan untuk memperoleh gambaran tentang bagaimana proses implementasi dan pelembagaan web-based learning berlangsung di Jurusan Kurikulum danTeknologi Pendidikan Fakultas Ilmu Pendidikan Universitas Negeri Jakarta. Target khusus penelitian ini adalah mengembangkan suatu model pengadopsian suatu inovasi pembelajaran oleh suatu lembaga, dalam hal ini inovasi belajar berbasis jaringan. Tujuan dari suatu implementasi inovasi adalah menjamin penggunaan yang benar oleh individu dalam organisasi. Tujuan pelembagaan adalah mengintegrasikan inovasi tersebut ke dalam struktur dan kehidupan organisasi. Metode penelitian yang digunakan adalah studi kasus dimana peneliti menyelidiki suatu gejala dalam konteks yang sebenarnya. Seiring dengan itu digunakan juga "Model Keputusan Adopsi Inovasi dalam Organisasi" oleh Everett M. Rogers, dalam rangka memahami tahapan-tahapan proses implemantasi dan pelembagaan. Sumber data dari penelitian ini terdiri dari pemrakarsa dan para pioner web-bali. Hasil dari penelitian ini berupa suatu Model Pelembagaan web-based learning indonesia (web-bali) yang meliputi tahap pencanangan agenda, tahap pencocokan, penstrukturan, klarifikasi dan rutinisasi.
\end{abstract}

Kata kunci: inovasi, implementasi, pelembagaan, web-based learning

\section{INSTITUTIONALIZATION WEB-BASED LEARNING DEPARTMENT OF TECHNOLOGY EDUCATION CURRICULUM AND STATE UNIVERSITY FACULTY OF EDUCATION JAKARTA}

\author{
Eveline Siregar \\ evelinesiregar@gmail.com
}

Program Studi Teknologi Pendidikan Fakultas Ilmu Pendidikan Universitas Negeri Jakarta

\begin{abstract}
The general purpose of this research is to observe implementation and institutionalization of web-based learning in Curricullum and Educational Technology Program, Faculty of Education, State University of Jakarta. The specific purpose of this research is to model the adoption of an innovation by an institution where web-based learning is the innovation. Implementation of innovation ensures correctness of individual usage in an organization. While institutionalization integrates innovation to organization structure and activities. The chosen research method is case-study where researchers study of a phenomenon in rea-life context. This research also uses the "Model of Innovation Adoption Decision in Organization" (Everett M. Rogers) to understand steps of implementation and institutionalization. The sources of information for this research are founders and pioneers of WebBali. The product of this research is an Indonesian web-based learning institutionalization model (Web-Bali) which consists of agenda setting, matching, redefining/restructuring, clarifying and routinizing.
\end{abstract}

Keywords: innovation, implementation, institutionalization, web-based learning 


\section{Pendahuluan}

Saat ini perkembangan teknologi informasi dan komunikasi berkembang sangat pesat terlebih dengan adanya teknologi Internet. Internet saat ini sudah banyak dimanfaatkan di berbagai bidang, salah satunya adalah di bidang pendidikan. Pola pemanfaatan internet di bidang pendidikan dikenal dengan konsep e-Learning. Secara umum definisi e-learning sebagai penyampaian program pembelajaran, pelatihan atau pendidikan dengan menggunakan sarana elektronik seperti komputer atau alat elektronik lain seperti telepon genggam dengan berbagai cara untuk memberikan pelatihan, pendidikan atau bahan ajar. Namun demikian, pada perkembangannya saat ini konsep e-Learning cenderung diidentikan dengan pola pembelajaran menggunakan internet. Ada banyak istilah atau terminologi baru yang muncul dari konsep e-Learning mengacu pada kata $e$ learning, seperti virtual learning, online learning, virtual class, e-training, dan web based learning, serta blended learning.

Jurusan Kurikulum dan Teknologi Pendidikan Fakultas Ilmu Pendidikan Universitas Negeri Jakarta (KTP FIP UNJ) adalah salah satu jurusan yang telah melakukan inisiasi menerapkan konsep e-Learning dengan spesifikasi khusus yaitu web based learning dalam proses pembelajarannya. Jika konsep e-Learning merupakan sebuah proses pembelajaran yang dikembangkan dengan menggunakan bantuan alat elektronik, maka untuk web based learning proses pembelajaran dilaksanakan dengan menggunakan sebuah website yang telah dirancang untuk "merekam dan menyampaikan" seluruh proses pembelajaran.

Penerapan web based learning sudah sejak lama diterapkan oleh beberapa dosen Jurusan Kurikulum dan Teknologi Pendidikan, tetapi diterapkan secara resmi dimulai sejak bulan Mei tahun 2009 yang ditandai dengan peluncuran situs resmi jurusan yaitu www.web-bali.net. Adapun saat ini penerapan web based learning di
KTP FIP UNJ menggunakan platform claroline.

Implementasi web-based learning pada Jurusan KTP FIP UNJ bukanlah proses yang mudah dan merupakan upaya yang memerlukan proses panjang, baik sebelum diluncurkan pada tahun 2009, maupun ketika sudah proses peluncuran. Pada tahapan awal hingga saat ini banyak hal yang dilakukan oleh Jurusan KTP FIP UNJ dalam melembagakan web based learning. Pada kesempatan ini akan diuraikan proses implementasi dan pelembagaan web based learning sebagai sebuah inovasi di Jurusan KTP FIP UNJ.

\section{Definisi Implementasi dan Pelembagaan}

Menurut Seels \& Richey (1994), proses implementasi dan pelembagaan berada dalam kawasan pemanfaatan. Implementasi adalah penggunaan bahan dan strategi pembelajaran dalam keadaan yang sesungguhnya (bukan tersimulasikan. Sedangkan pelembagaan adalah penggunaan yang rutin dan pelestarian dari inovasi pembelajaran dalam suatu struktur atau budaya organisasi. Inovasi yang akan dibahas dalam artikel kali ini adalah web based learning. Implementasi dan pelembagaan tergantung pada perubahan individu maupun organisasi. Tujuan dari implementasi ialah menjamin penggunaan yang benar oleh individu dalam organisasi. Sedang tujuan dari pelembagaan ialah untuk mengintregrasikan inovasi dalam struktur dan kehidupan organisasi (Cuban,1986).

Michael Fullan, mendefinisikan implementasi sebagai “... penggunaan nyata dari suatu inovasi dalam praktek keseharian". Lebih lanjut, ia menyebut perspektif implementasi dapat berupan isi dan proses yang berhubungan dengan ide-ide, program, kegiatan, struktur, dan kebijakan yang baru kepada orang-orang yang terlibat" (Fullan, 1996).

Implementasi harus mengarah secara alami ke pelembagaan. Beberapa penulis menyebutnya pelembagaan dengan "rutinisasi" atau Kriteria utama sukses inovasi 
adalah bahwa inovasi itu secara rutin digunakan dalam pengaturan yang dirancang secara "keberlanjutan", dan hal ini telah menjadi bagian integral dari organisasi atau sistem sosial dan tidak lagi dianggap menjadi sebuah inovasi.

Sebuah karya klasik mendefinisikan pelembagaan sebagai suatu asimilasi elemen perubahan menjadi sebuah organisasi yang terstruktur dalam memodifikasi organisasi dengan cara yang stabil (Miles, Eckholm, \& Vandenburghe, 1987).

Menurut the Regional Laboratory for Educational Improvement of the Northeast and Islands (Eiseman, Fleming \& Roody, 1990), terdapat enam indikator yang mencirikan terjadinya Pelembagaan: (1) penerimaan inovasi oleh partisipan yang terkait; (2) implementasi Inovasi yang stabil dan dirutinkan; (3) meluasnya penggunaan inovasi di seluruh lembaga atau organisasi; (4) adanya ketegasan dalam penggunaan praktek dan/atau produk dalam institusi atau organisasi; (5) kelanjutan tidak tergantung pada tindakan individu-individu tertentu, tetapi pada struktur, budaya organisasi atau prosedur; dan (6) secara rutin pengalokasian waktu dan uang

\section{Karakteristik Web Based Learning}

Seperti telah disebutkan sebelumnya, bahwa banyak anggapan yang memberikan pemahaman bahwa pengertian $e$ Learning dan web based learning adalah sama. Anggapan tersebut tidak sepenuhnya salah, karena web based learning merupakan bagian dari e-Learning, namun tidak semua $e$-Learning adalah web based learning. Adapun pengertian Web-based learning pada dasarnya adalah penerapan dan proses dari $e$ learning, seperti dikemukakan berikut ini.

"Education via the internet, network or stand alone computer, e-learning is essentially the networl-enabled transfer of skills and knowledge. E-learning refers to using electronics applications and processes to learn. E-learning applications and processes include web-based learning, com- puter based learning, virtual classroom and digital collaboration. Content is delivered via the internet, intranet/extranet or videotape, satellite TV and CD ROM. (quoted from internet.com)"

Menurut Susanna Tsai definisi webbased learning:

Web-based learning entails content in a Web browser (not just activities), and actual learning materials delivered in Web format. In this, Web-based learning is analogous to textbooks, where the content determines whether a book is a novel, a report, or a textbook.

Dalam penerapan web based learning memiliki keuntungan dan kerugian yaitu sebagai berikut. Keuntungannya adalah: (1) memiliki kemampuan menghubungkan sumber informasi dalam banyak format; (2) dapat menjadi pilihan yang efisien dalam menyampaikan bahan pembelajaran; (3) sumber daya dapat disediakan dari lokasi manapun dan kapan saja; (4) berpotensi dalam memperluas akses; (5) dapat mendorong belajar lebih mandiri dan aktif; dan (6) dapat menjadi bahan ajar tambahan dalam pembelajaran konvensional.

Adapun kelemahan web based learning adalah: (1) akses ke peralatan komputer yang sesuai dapat menjadi masalah bagi siswa; (2) peserta didik merasa frustrasi jika mereka tidak dapat mengakses grafik, gambar, dan klip video karena peralatan yang terbatas; (3) infrastruktur yang diperlukan harus tersedia dan terjangkau; (4) informasi dapat bervariasi dalam kualitas dan akurasi, sehingga bimbingan dan "clue" diperlukan; dan (5) siswa dapat merasa terisolasi

Pemanfaatan web-based learning dapat dilihat dari dua sudut pandang, yaitu dari sudut peserta didik dan guru.

\section{Dari Sudut Peserta Didik}

Dengan kegiatan web based learning dimungkinkan berkembangnya fleksibilitas belajar yang tinggi. Artinya, peserta didik dapat mengakses bahan-bahan belajar se- 
tiap saat dan berulang-ulang. Peserta didik juga dapat berkomunikasi dengan guru/ dosen setiap saat. Dengan kondisi yang demikian ini, peserta didik dapat lebih memantapkan penguasaannya terhadap materi pembelajaran.

Manakala fasilitas infrastruktur tidak hanya tersedia di daerah perkotaan tetapi telah menjangkau daerah kecamatan dan pedesaan, maka kegiatan web based learningakan memberikan manfaat (Brown, 2000) kepada peserta didik yang (1) belajar di sekolah-sekolah kecil di daerah-daerah miskin untuk mengikuti mata pelajaran tertentu yang tidak dapat diberikan oleh sekolahnya, (2) mengikuti program pendidikan keluarga di rumah (home schoolers) untuk mempelajarii materi pembelajaran yang tidak dapat diajarkan oleh para orang tuanya, seperti bahasa asing dan keterampilan di bidang komputer, (3) merasa phobia dengan sekolah, atau peserta didik yang dirawat di rumah sakit maupun di rumah, yang putus sekolah tetapi berminat melanjutkan pendidikannya, yang dikeluarkan oleh sekolah, maupun peserta didik yang berada di berbagai daerah atau bahkan yang berada di luar negeri, dan (4) tidak tertampung di sekolah konvensional untuk mendapatkan pendidikan.

\section{Dari Sudut Guru/Dosen}

Dengan adanya kegiatan web based learning( Soekartawi, 2002a,b), beberapa manfaat yang diperoleh guru/dosen/instruktur antara lain adalah bahwa guru/ dosen/ instruktur dapat: (1) lebih mudah melakukan pemutakhiran bahan-bahan belajar yang menjadi tanggung-jawabnya sesuai dengan tuntutan perkembangan keilmuan yang terjadi, (2) mengembangkan diri atau melakukan penelitian guna peningkatan wawasannya karena waktu luang yang dimiliki relatif lebih banyak, (3) mengontrol kegiatan belajar peserta didik. Bahkan guru/dosen/instruktur juga dapat mengetahui kapan peserta didiknya belajar, topik apa yang dipelajari, berapa lama sesuatu topik dipelajari, serta berapa kali topik tertentu dipelajari ulang, (4) mengecek apakah peserta didik telah mengerjakan soal-soal latihan setelah mempelajari topik tertentu, dan (5) memeriksa jawaban peserta didik dan memberitahukan hasilnya kepada peserta didik.

\section{Web Based Learning di Jurusan KTP FIP UNJ}

Pada tahun 2009 Jurusan KTP FIP UNJ meluncurkan web based learning sebagai produk inovatif. Nama produk web based learning yang dikembangkan Jurusan KTP FIP UNJ adalah campus of webbased learning Indonesia (web-bali), dengan subdomain www.courses.web-bali.net. Sasaran pengguna dari produk ini adalah mahasiswa S1 KTP FIP UNJ. Spesifikasi sistem pada produk web based learning di Jurusan KTP FIP UNJ adalah: (1) website ini dikembangkan dengan server kapasitas hosting 3 GB, dengan kapasitas Traffic data transfer sebesar 200 GB per bulan; dan (2) menggunakan Platform LCMS Claroline.

Dari proses pengembangannya, web-based learning memiliki beberapa kelebihan yaitu sebagai beriku. Pertama, dirancang dengan konsep pembelajaran yang menyeluruh disegala aspek. Kedua, aksesbilitas tinggi, hal ini dibuktikan dengan akses yang dapat dilakukan melalui mobile internet; Ketiga, fleksibilitas tinggi bagi pengembang konten. Fleksibilitas ini terlihat dari bebasnya content designer dalam memilih aplikasi apa saja yang akan digunakan dalam kelas virtualnya. Keempat, pembelajaran melalui website ini sudah dapat diakui pelaksanaannya, karena sudah terdapat Tracking Progress, sehingga dimilkinya catatan detail bagi mahasiswa dan dosen yang mengakses pembelajaran. Hal ini tentunya dapat mengganti form 05/06 (daftar hadir dosen dan daftar hadir mahasiswa) yang biasa digunakan pada pembelajaran tatap muka.

Selain kelebihan yang diuraikan, web based learning juga memiliki keterbatasan. Keterbatasan pada pengembangan web based learning ini adalah belum dilakukannya revisi yang menyeluruh pada 
web based learning sebagai produk hasil inovasi.

Untuk memanfaatkan website ini memang bukanlah hal yang sederhana, oleh karena itu akan dipersiapkan buku panduan baik cetak dan digital bagi mahasiswa untuk mengakses di www.webbali.net, sedangkan bagi dosen prosedur pemanfaatan disosialisasikan melalui pelatihan-pelatihan yang dilakukan secara berkala.

Kondisi-Kondisi yang Mempengaruhi Pelembagaan Inovasi

Donald P. Ely (1990) mengemukakan beberapa kondisi-kondisi yang mempengaruhi implementasi dan pelembagaan suatu inovasi. Menurut Donald P.Ely ada beberapa kondisi yang memfasilitasi diadopsi dan diimplementasikannya suatu inovasi pendidikan. Kebanyakan kondisikondisi tersebut berasal dari kepustakaan di perguruan tinggi di beberapa negara berkembang dan dari pengalaman pribadi si pengarang. Validasi lanjutan akan memperkuat, menolak atau memodifikasi kondisi-kondisi tersebut sebagaimana dipandang dari berbagai latar dan kawasan. Kehadiran delapan kondisi tersebut sangat dibutuhkan untuk mengimplementasikan perubahan, sekali suatu inovasi sudah diperkenalkan dan diadopsi. Pengurangan salah satu kondisi akan mengakibatkan berkurangnya kemungkinan untuk dilanjutkannya suatu inovasi. Kehadiran hanya dua atau tiga kondisi saja akan memperlemah implementasi dan kecil kemungkinan untuk dilanjutkan. Kondisi-kondisi tersebut adalah sebagai berikut.

Pertama, kekecewaan (dissatisfaction) terhadap keadaan yang yang ada khususnya dalam belajar dan pembelajaran, sehingga mendorong dilakukannya suatu inovasi. Kedua, pengetahuan atau keterampilan (knowledge/skills) yang dibutuhkan untuk melaksanakan suatu suatu inovasi. Suatu inovasi akan diadopsi dan diimplementasikan, jika individu sudah memiliki pengetahuan dan keterampilan untuk melaksanakan inovasi tersebut. Salah satu aspek dari setiap adopsi inovasi adalah memasukkan pelatihan untuk membantu dosen dalam menggunakan suatu produk atau prosedur yang baru.

Ketiga, penghargaan atau dorongan (rewards/incentives) untuk menerima dan melanjutkan suatu inovasi. Bentuk-bentuk penghargaan sangat bervariasi, bergantung pada sistem nilai pada masing-masing individu Ada beberapa orang yang memandang adanya permintaan sebagai konsultan pendidikan dan pelatihan yang memerlukan kompetensinya dan dapat menunjukkan inovasi yang dilakukan, merupakan suatu penghargaan, juga dapat meningkatkan pendapatan. Adanyanya pengakuan dari orang-orang di bidang pendidikan dan pelatihan terhadap indivi-du yang berhasil mengimplementasikan suatu inovasi, selanjutnya ia akan dicari oleh mereka yang membutuhkan batuan dalam mendesain dan mengembangkan suatu pelatihan.

Keempat, waktu (time) untuk merencanakan dan mengimplementasikan suatu inovasi. Setelah pelatihan untuk mengadopsi inovasi dilaksanakan, harus segera dibuat perencanaan untuk penggunaan inovasi. Berarti harus mengintegrasikan inovasi dengan prosedur yang sudah ada atau menciptakan prosedur yang baru. Dengan kata lain, dalam mengimplementasikan suatu inovasi perlu dialokasikan waktu untuk merencanakan, menyampaikan dan mengevaluasi inovasi tersebut.

Kelima, sumber-sumber (resources) yang digunakan untuk implementasi suatu inovasi, meliputi bahan-bahan dan peralatan yang dibutuhkan untuk melaksanakan suatu pekerjaan inovasi. Sumber daya manusia dan sumber daya waktu tidak termasuk dalam pengertian ini, mereka tergabung ke dalam kondisi yang lain. Peralatan atau perangkat keras bisa diartikan sebagai sistem penyampaian yang canggih. Bahan atau perangkat lunak atau software digunakan untuk melengkapi peralatan.

Keenam, kepemimpinan (leadership) dalam memperkenalkan dan melanjutkan 
suatu inovasi sangat penting. Pemimpin adalah orang-orang dalam posisi yang tinggi yang menganjurkan atau mendukung suatu gerakan dan secara aktif memfasilitasi proses difusinya.

Ketujuh, komitmen (commitment) dalam diri setiap orang yang terlibat dalam inovasi. Komitmen yang pertama kali dipegang oleh seorang pemimpin. Komitmen berhubungan dengn suatu isu atau kegiatan yang tidak mudah digoncangkan. Dimensi lain yang melebihi komitmen dari pemimpin adalah komitmen dari personil pelaksana inovasi tersebut, misalnya dekan, ketua jurusan dan dosen-dosen yang pada akhirnya harus menunjukkan komitmen terhadap inovasi apapun dalam proses pembelajaran. Untuk melihat komitmen adalah dengan melihat perubahan perilakunya, melaksanakan inovasi dalam pekerjaannya sehari-hari dan mendapatkan umpan balik dari sejawat maupun mahasiswa yang menjadi sasaran.

Kedelapan, partisipasi (participation dalam proses inovasi. Lebih aktif seseorang dalam diskusi, adopsi, difusi, implementasi dan pelembagaan suatu inovasi, akan lebih besar kemungkinan inovasi tersebut berhasil. Jika dosen-dosen diminta untuk menggunakan suatu inovasi namun tidak menjadi bagian dari keputusannya sendiri (dipaksakan dari atasan), kemungkinan mereka akan menolaknya. Melibatkan setiap orang yang mungkin menjadi pengguna inovasi di masa yang akan datang untuk berpartisipasi dalam diskusi tentang kegunaannya, akan lebih memungkinkan inovasi tersebut diadopsi. Juga individu yang terlibat akan mendukung, menganjurkan dan membantu orang lain untuk melakukan hal yang sama.

Banyak inovasi ditujukan kepada organisasi sebagai unit pengadopsinya. Dalam kasus demikian, pembuat keputusan adalah pemegang otoritas dalam organisasi. Seseorang -dalam organisasi sebagai individu tidak dapat mengadopsi suatu ide baru sebelum suatu organisasi di mana ia menjadi anggotanya mengadopsi inovasi tersebut. Proses keputusan inovasi dalam organisasi lebih kompleks dan rumit dibanding proses keputusan inovasi oleh individu.

Meskipun ada kesamaan jumlah tahapan antara proses keputusan inovasi individual dan proses keputusan inovasi dalam organisasi ini, namun terdapat perbedaan dalam prosesnya. Dalam proses individual, proses keputusan adopsi diawali dengan kesadaran pengetahuan, sedangkan dalam proses keputusan inovasi dalam organisasi, tahap pertamanya adalah terjadinya kesadaran akan adanya masalah organisasi yang memerlukan atau membutuhkan inovasi. Akhir dari proses keputusan inovasi dalam organisasi adalah rutinisasi, di mana suatu ide baru telah dianggap sebagai suatu bagian dari organisasi. Proses keputusan inovasi dalam organisasi ini pada umumnya lebih memerlukan waktu jika dibanding dengan proses keputusan inovasi individual.

\section{Metode Penelitian}

etode peneltian yang digunakan adalah studi kasus dimana penelitian ini merupakan pengkajian yang mendalam, melibatkan beberapa gejala, dilakukan dalam konteks yang sebenarnya dan merefleksikan sudut pandang dari partisipan yang terlibat dalam gejala (Borg and Gall, 2007). Langkah-langkah penelitian meliputi merumuskan masalah penelitian, menetukan sumber data, mengumpulkan data dan menganalisis data.

Tujuan dari pelembagaan Web-based learning di Jurusan Kurikulum dan Teknologi Pendidikan FIP UNJ adalah untuk mengintregrasikan inovasi tersebut dalam struktur dan kehidupan organisasi. Dengan demikian proses implementasi dan pelembagaan yang baik harus berjalan sesuai dengan tahapan-tahapan yang benar, untuk itu digunakan "Model Keputusan Adopsi lnovasi dalam Organisasi" oleh Everett. M. Rogers, sebagai acauan.

Proses pengambilan keputusan adopsi inovasi oleh organisasi yang dikemukakan oleh Rogers melalui beberapa 
tahapan, yaitu mulai dari penyusunan agenda (agenda setting), penyesuaian (matching), definisi ulang atau restrukturisasi (redefining/ restructuring), klarifikasi (clarifyng) dan rutinisasi (routinizing). Seluruh tahapan tersebut dapat dikelompokkan menjadi dua tahapan besar yaitu tahap inisiasi dan tahap implementasi. Batas antara kedua tahap tersebut ditandai oleh suatu keputusan adopsi.

Secara rinci, lima tahapan yang dilakukan dalam keputusan adopsi inovasi oleh organisasi adalah sebagai berikut.

Pertama adalah penyusunan agenda. Penyusunan agenda atau agenda setting terjadi dalam proses inovasi ketika masalah umum organisasi telah dinyatakan menimbulkan kebutuhan inovasi. Proses ini berlangsung kapan saja dalam setiap sistem. Penyusunan agenda ini merupakan cara untuk menentukan urutan prioritas di antara berbagai kebutuhan, masalah dan isu- isu yang perlu mendapat perhatian. Pada tahap penyusunan agenda ini, satu atau beberapa orang dalam organisasi mengidentifikasi masalah penting dan kemudian mencari inovasi sebagai pemecahan masalah. Suatu kesenjangan kinerja dapat memacu proses inovasi pada tahap ini. Kesenjangan kinerja adalah selisih antara harapan organisasi dengan kinerja yang ada atau kinerja aktual. Penyusunan agenda ini berlangsung ketika suatu organisasi merumuskan kembali visi dan misinya, atau ketika organisasi menetapkan strategi untuk pencapaian visi dan misi.

Kedua, penyesuaian atau matching adalah suatu tahapan dalam proses inovasi di mana masalah organisasi dicocokkan dengan suatu inovasi tertentu (ide baru tertentu), dan penyesuaian ini direncanakan dan dirancang. Pada tahap penyesuaian ini masalah-masalah secara konseptual dicocokkan dengan ide baru tersebut untuk mengetahui seberapa banyak kecocokan dan kebaikannya. Pada tahap penyesuaian ini ada dua kemungkinan yang bisa terjadi. Pertama, organisasi akhimya harus menyesuaikan dengan ide baru tertentu, sehingga terjadi perubahan-perubahan dalam organisasi. Kemungkinan kedua adalah ide baru tertentu tersebut disesuaikan dengan organisasi sebelum akhirnya diadopsi atau menjadi bagian dari organisasi tersebut.

Ketiga, redefinisi/restrukturisasi. Pada tahap ini inovasi yang diambil dari luar organisasi secara perlahan kehilangan ciri-ciri asingnya. Redefinisi atau restrukturisasi terjadi ketika inovasi dimodifikasi atau diciptakan kembali untuk mengakomodasikan kebutuhan atau agar sesuai dengan struktur organisasi, dan ketika struktur organisasi dimodifikasi agar sesuai dengan inovasi. Jadi kedua belah pihak, yaitu organisasi dan inovasi/ide baru tertentu diharapkan berubah pada tingkatan tertentu selama proses redefinisi/restrukturisasi. Akhirnya dapat kita simpulkan bahwa antara inovasi dan struktur organisasi ada pengaruh timbal balik. Selain itu ada kaitan pula antara inovasi dan ketidakpastian organisasi, artinya tidak ada garansi bahwa dengan inovasi/ide baru tersebut organisasi pasti memperoleh manfaat. Secara lebih konkrit tahapan ini bisa menghasilkan dua kemungkinan yaitu; (1) organisasi berubah visi dan misinya karena adanya inovasi/ide baru tertentu, atau (2) inovasi berubah strukturnya ketika diadopsi oleh suatu organisasi.

Keempat, adalah klarifikasi. Klarifikasi terjadi ketika inovasi telah dipergunakan secara luas dalam suatu organisasi, dan makna suatu ide baru pelanpelan menjadi semakin jelas bagi anggota organisasi. Implementasi suatu inovasi yang terlalu cepat pada tahap klarifikasi seringkali menyebabkan terjadinya kegagalan. Bisa saja hal tersebut menimbulkan salah faham atau terjadinya akibat yang tidak diinginkan dari suatu inovasi. Tahap klarifikasi dalam proses inovasi pada suatu organisasi merupakan konstruksi sosial, sehingga makna inovasi dikembangkan terus melalui suatu proses sosial yakni interaksi manusia.

Kelima adalah rutinisasi. Rutinisasi terjadi ketika inovasi menjadi aktivitas 
yang wajar bagi suatu organisasi, dan inovasi telah kehilangan perbedaan identitas. Pada tahap ini proses inovasi telah dianggap selesai. Para anggota organisasi tidak lagi menganggap inovasi tersebut sebagai hal baru.

Dalam menerapkan model keputusan adopsi inovasi oleh organisasi yang diajukan Rogers, dalam proses pengambilan data dan penarikan kesimpulan pada tahapan-tahapan tersebut diintegrasikan dengan metode penelitian studi kasus.

\section{Hasil dan Pembahasan}

Seperti telah dikemukakan, bahwa tujuan dari penelitian ini adalah mengembangkan Model Pelembagaan Web-Based Learning di Jurusan KTP FIP UNJ. Penelitian studi kasus ini bertujuan memberikan penjelasan tentang gejala yang diselidiki, dalam hal ini mendeskripsikan implementasi dan pelembagaan inovasi web-based learning. Kerangka kerja (framework) dari Rogers dan Ely yang digunakan untuk membahas hasil penelitian, yang meliputi tahap pencanangan agenda (agenda setting), pencocokan (matching), penstrukturan/ pendefinisian ulang (structuring/redefining), klarifikasi (clarifying), dan rutinisasi (routinizing).

\section{Pencanangan Agenda (Agenda Setting)}

Pada tahap ini mulai diidentifikasi beberapa masalah penting dalam organisasi, khususnya di Jurusan Kurikulum dan Teknologi Pendidikan dan kemudian mencari inovasi sebagai pemecahan masalah. Dari hasil wawancara yang dilakukan terhadap pemrakarsa web-bali yaitu Dra. Dewi S. Prawiradilaga, M.Sc di dapat informasi masalah utama yang ingin dipecahkan dengan adanya web-bali dalam pembelajaran ini adalah birokrasi yang rumit dan fasilitas dan insfrastruktur kampus yang kurang memadai untuk menunjang mahasiswa dalam belajar secara konvensional. Di sisi lain, adanya perkembangan teknologi informasi dan komunikasi yang pesat sebagai potensi proses pembelajaran modern belum diimplementasikan. Sehingga jurusan KTP mengambil inisiatif untuk memcahkan masalah pembelajaran dengan menerapkan pendayagunaan TIK, khususnya pembelajaran berbasis website.

Untuk memperoleh informasi untuk mengembangkan suatu inovasi untuk memecahkan masalah tersebut pemrakarsa web-bali melakukan diskusi dengan rekan sejawat, browsing melalui internet,uji coba sendiri dan melakukkan Library research. Untuk mengembangkan web-bali pemrakarsa melakukkan beberapa langkah-langkah, yaitu, langkah pertama melakukkan prototyping mata kuliah tertentu, langkah ke dua yaitu diskusi dengan kolega dan rekan sejawat, dan yang ketiga adalah mendesain content dan learning object dan langkah yang terakhir adalah field setting atau pengaturan lapangan untuk mempersiapkan pemanfaatan web- bali dalam pembelajaran.

Selain menggali informasi dengan wawancara dengan pemrakarsa juga dilakukan wawancara dengan para pioner pemanfaatan web-bali, yaitu Murti Wirasti Kusuma, M.Si, Kunto Imbar N, S.Pd, Diana Ariani, S.Pd, dan Uwes A, Chaeruman, M.Pd. Berdasarkan wawancara dengan para pioneer web-bali masalah-masalah yang dirasakan dan dicarikan solusinya melalui suatu inovasi adalah: (1) pemberian pengalaman belajar kepada mahasisiwa secara terkonstruksi sesuai dengan tujuan pembelajaran; (2) masalah infrastruktur kelas dan jumlah dosen yang kurang memadai untuk berlangsungnya perkuliahan yang efektif dan efisien; (3) paradigma pembelajaran modern yaitu pengintegrasian TIK secara tepat guna dan tetap berorientasi keapada mahasiswa.

Pada umumnya seluruh pioner web-bali menyatakan bahwa mereka semua setuju bahwa pemanfaatan web-bali dalam pembelajaran merupakan suatu solusi untuk pemecahan masalah-masalah tersebut. Disamping itu, para pionir menyatakan bahwa penerapan pembelajaran berbasis web melalui web-bali ini merupa- 
kan suatu keharusan bagi program studi teknologi pendidikan sebagai upaya penerapan dari konsep teknologi pendidikan itu sendiri di lingkungan lembaga pendidikan yang mempelajari disiplin ilmu teknologi pendidikan.

Dengan demikian dapat disimpulkan bahwa permasalahan yang melatarbelakangi pencanangan agenda penyelenggaraan pembelajaran berbasis web melalui web-bali adalah sebagai berikut.

Pertama, infrastruktur dan fasilitas pembelajaran yang tidak memadai yang ditunjukkan dengan rumitnya birokrasi, kurangnya ruangan kelas, dan sulitnya pengaturan jawdwal kuliah. Kedua, adanya teknologi dan sumber belajar baru yang belum dimanfaatkan di program studi teknologi pendidikan, bahkan di Universitas Negeri Jakarta itu sendiri. Teknologi dan sumber belajar tersebut adalah kehadiran teknologi informasi dan komunikasi, khususnya internet dengan segala tool dan aplikasi yang ditawarkan menimbulkan keinginan bagi pemprakarsa dan pionir untuk mencoba menyelenggaraan pembelajaran dengan teknologi kontemporer dalam hal ini adalah pemeblajaran berbasis web.

Ketiga adalah objek formal teknologi pendidikan adalah memecahkan masalah belajar. Kondisi seperti ini menarik perhatian pemrakarsas dan pionir untuk menerapkan disiplin ilmu ke-TP-an, dalam hal ini adalah penerapan pembelajaran berbasis web.

\section{Pencocokan (Matching)}

Pada tahap pencocokan dilakukan pengumpulan data kepada pemrakarsa, pionir dan mahasiswa. Dari pengumpulan data diperoleh data bahwa penerapan pembelajaran berbasis web, cocok dengan ide dan keinginan dari pemrakarsa dan para pionir (5 orang staf dosen) yang telah familiar dengan komputer dan internet.

Kedua, sejak tahap inisiasi, penerapan pembelajaran berbasis web mendapat respon positif dari para mahasiswa. Kecocokan dari mahasiswa dilihat dari bebe- rapa pernyataan berikut. (1) belajar berbasis web di web-bali memberikan kesempatan untuk belajar mandiri (menyesuaikan dengan kebutuhan, situasi dan kondisi masing- masing) dan bahkan dapat belajar kapan saja dan dimana saja); (2) belajar berbasis web di web-bali memotivasi mahasiswauntuk terbiasa memanfaatkan dan mencari informasi di internet; dan (3) belajar berbasis web di web-bali membuat mahasiswa berani berkomunikasi dan mengemukakan pendapat walaupun tidak langsung di kelas tapi secara virtual melalui e-mail, chatting, dan forum diskusi.

\section{Redefinisi dan Penstrukturan Ulang}

Redefinisi/restrukturisasi terjadi ketika inovasi dimodifikasi atau diciptakan kembali untuk mengakomodasikan kebutuhan atau agar sesuai dengan struktur organisasi, dan ketika struktur organisasi dimodifikasi agar sesuai dengan inovasi. Berdasarkan hasil wawancara dengan pemrakarsa web-bali diperoleh informasi bahwa ketika akan memanfatkan web-bali dalam proses pembelajaran terjadi penyesuaian-penyesuaian yang harus dialakukan yaitu, content design, dan perubahan mindset dari mahasiswa dan dosen. Selain itu dengan penerapan web-bali menurut pemrakarsa web-bali juga terjadi modifikasi dari struktur organisasi dari jurusan TP yaitu perubahan anggaran pertahun, dan organisasi SDM, dengan adanya webmanager.

Sedangkan hasil wawancara dengan para pionir, mereka menyatakan bahwa mulai mempelajari lebih dalam platform web-bali yang digunakan, seperti karaketristik format bahan ajar yang memungkinkan digunakan, teknik pengembangan dan pengunggahan bahan ajar, serta pemanfaatan fasilitas lain seperti forum diskusi, tugas dan lain-lain. Lebih jauh lagi, para pionir mulai mencoba melakukan kombinasi blended learning yang berbeda sesuai dengan kondisi dan karakteristik daripada pata kuliah itu sendiri. 
Informasi lain yang diperoleh dari pemrakarsa adalah, pada tahap ini telah dietapkan secara bulat bahwa web-bali, menggunakan platform opensource. Platform claroline menjadi pilihan karena sesuai dengan karakteristik alur pembelajaran yang dianut di program studi teknologi pembelajaran.

Dengan demikian, dapat disimpulkan bahwa sebagai tindak lanjut dari tahap pencocokan, telah terjadi redefinisi/restrukturisasi inovasi web-bali. Redefinisi yang terjadi, diantaranya adalah: (1) perubahan mindset pionir dalam melaksanakan web-bali, yang menkerucut pada persepsi yang sama muali dari tahap desain pembelajaran berbasis web, pengembangan bahan ajar (konten) dan implementasi; (2) mulai dibentuk struktur organisasi pengelolaan pembelajaran berbasis web; (3) para pionir mulai mengembangkan model blended learning sendiri dengan memanfaatkan web-bali menyesuaikan dengan kebutuhan dan karakteristik mata kuliah masing-masing; dan (4) penetapan penggunaan Claroline sebagai platform resmi learning management system web-bali.

Klarifikasi terjadi ketika inovasi telah dipergunakan secara luas dalam suatu organisasi, dan makna suatu ide baru pelan-pelan menjadi semakin jelas bagi anggota organisasi. Berdasarkan hasil wawancara dengan pemrakarsa web-bali diperoleh informasi bahwa web-bali dimanfaatkan sebagai salah satu strategi pembelajaran dalam perkuliahan sehari-hari sejak tahun akademik 2008/2009. Sebanyak $35 \%$ dari staf pengajar ikut mengembangkan dan memanfaatkan web-bali dalam perkuliahan, tetapi belum semua staf pengajar di jurusan KTP memahami fungsi webbali dalam perkuliahan. Selain itu menurut pemrakarsa web-bali, para mahasiswa belum terbiasa dalam menggunakan tools yang ada dalam web-bali.

Hasil wawancara juga menginformasikan bahwa, pada tahap ini, para pionir masih memiliki komitmen tinggi dalam memanfaatkan web-bali dalam proses pembelajaran, sementara dosen lain yang masih dalam tahap mencoba. Beberapa aktifitas penguatan sumber daya manusia dilakukan oleh pihak Jurusan KTP untuk memperkuat pemanfaatan web-bali diantaranya adalah dengan melakuksanakan lokakarya pengembangan konten berbasis web bagi para dosen, melakukan survey pemanfaatan web-bali, dan pengembangan desain pembelajaran berbasis web yang dapat dijadikan sebagai model bagi dosen lain.

Sementara, secara umum mahasiswa tetap merespon positif pelaksanaan pembelajaran berbasis web. Beberapa indikator terjadinya klarifikasi penerapan pembelajaran berbasis web melalui webbali adalah sebagai berikut: (1) $60 \%$ mahasiswa menyatakan bahwa dosen yang telah menerapkan pembelajaran berbasis web senantiasa secara konsisten memperbaharui dan mengembangkan konten web-bali; (2) $70 \%$ mahasiswa menyatakan bahwa pemanfaatan web-bali sudah efektif; (3) $64 \%$ mahasiswa menyatakan bahwa pembelajaran melalui web-bali telah sesuai dengan kebutuhan belajar mereka.

Dengan demikian, pada tahap ini klarifikasi telah terjadi dengan indikasi sebagai berikut: (1) web-bali resmi digunakan sebagai sarana pembelajaran sejak tahun akademik 2008/2009; (2) 35\% staf pengajar di Program Studi Teknologi Pendidikan telah mulai memanfaatkan webbali; (3) para pionir tetap melaksanakan perkuliahan dengan memanfaatkan webbali; (4) pihak program studi teknologi pendidikan telah melakukan penguatan SDM dengan melakukan beberapa kegiatan seperti lokakarya pengembangan konten pembelajaran berbasis web, sosialisasi webbali, dan pengembangan desain pembelajaran berbasis web untuk beberapa mata kuliah sebagai model bagi dosen lain; (5) mahasiswa menyatakan bahwa pembelajaran melalui web-bali cukup efektif, dan sesuai dengan kebutuhan mereka.

\section{Rutinisasi (Routinization)}

Rutinisasi terjadi ketika inovasi menjadi aktivitas yang wajar bagi suatu 
organisasi, dan inovasi telah kehilangan perbedaan identitas, para anggota organisasi tidak lagi menganggap inovasi tersebut sebagai hal baru.

Berdasarkan hasil waancara dengan pemrakarsa web-bali maka diperoleh informasi bahwa sebagai bukti yang dapat menunjukkan bahwa web-bali sudah menjadi bagian dari insfrastruktur Jurusan KTP FIP UNJ adalah dengan dicantumkannya web-bali ke dalam Buku Pedoman Akademik (BPA) dan rencana strategis FIP UNJ. Setidaknya kurang lebih 20 mata kuliah yang telah memanfaatkan web-bali. Selain hal tersebut pada tahap ini diperoleh pula data sebagai berikut: (1) umumnya pionir telah menggunakan web-bali dalam perkuliahan yang diikuti oleh para dosen lainnya; (2) selain itu setiap orang yang diperkirakan menjadi pengguna web-bali di masa yang akan datang sudah dilibatkan dalam diskusi tentang pemanfaatan web-bali; (3) para pioner juga sudah secara aktif berpartisipasi dalam pengembangan web-bali, juga sudah mengadopsi, mendukung, menganjurkan dan membantu orang lain yang membutuhkan hal yang sama, umumnya yang mereka bantu adalah rekan sejawat mereka, dan lembaga lain diluar Jurusan KTP FIP UNJ seperti pusat pendidikan kilat kemetrian agama dan kementrian kesehatan.

Dengan demikian dapat disimpulkan bahwa pelembagaan inovasi pembelajaran berbasis web melalui web-bali baru terjadi pada pemrakarsa dan pionir sebagai inovator dan early adopter. Upaya-upaya pelembagaan masih perlu terus dilakukan untuk para dosen lain yang dapat dikategorikan dalam kelompok majority menurut framework difusi inovasi Rogers.

\section{Simpulan dan Saran}

Simpulan

Penerapan suatu inovasi, apapun itu memerlukan strategi tersendiri. Rogers memberikan framework dalam melaksanakan suatu pelembagaan inovasi dalam organisasi yang meliputi lima tahap seperti dijelaskan di atas. Tahapan ini dapat dijadikan patokan dalam melembagakan suatu inovasi. Dalam konteks ini, program studi teknologi pendidikan dapat menyimpulkan bahwa pelembagaan inovasi berupa pembelajaran berbasis web melalui web-bali masih belum sempurna khususnya dalam tahap klarifikasi dan rutinisasi.Hal yang sama bisa dilakukan oleh lembaga lian yang melakukan hal yang relatif sama.

Berdasarkan informasi hasil penelitian seperti dijelaskan di atas dapat disimpulkan bahwa program studi teknologi pendidikan masih memerlukan berbagai upaya dalam pelembagaan inovasi pembelajaran berbasis web melalui web-bali. Perhatian lebih ditekankan pada tahap klarifikasi dan rutinisasi.

\section{Saran}

Beberapa hal yang dapat direkomendasikan dari hasil penelitian ini adalah sebagai berikut.

Pertama, sebagai upaya memperkuat tahap klarifikasi, para dosen pionir hendaknya menunjukkan "best practice" sebagai model bagi dosen lain baik dari sisi keuntungan relatif bagi dirinya maupun mahasiswa, maupun contoh implementasi (seperti contoh desain pembelajaran, pengemasan bahan ajar, dan lain-lain).

Kedua, para pionir sebagai agen pembaharu, sebaiknya mulai mendekati staf dosen lain yang dianggap telah memasuki level early adopter, dengan ciri-ciri mudah menerima hal baru, familiar dengan teknologi informasi dan komunikasi, dan sejenisnya.

Ketiga, pihak program studi perlu terus melakukan upaya peningkatan kapasistas dosen dalam menerapkan pembelajaran berbasis web melalui berbagai bentuk intervensi baik yang bersifat instruksional seperti pelatihan, coaching, mentoring, maupun non-instruksional s-perti pembudayaan ICT, penataan fasilitas, pemberian insentif yang relevan, dan lain-lain.

Keempat, pihak program studi, fakultas, dan bahkan universitas, sebaiknya dapat mengeluarkan kebijakan-kebijakan 
yang dapat mendorong peningkatan penerapan pembelajaran berbasis web yang tepat guna. Seperti, perubahan kebijakan akademik, pemberian award tahunan bagi dosen, program studi yang berhasil menerapkan pembelajaran berbasis web, peningkatan infrastruktur dan fasilitas akses terhadap teknologi informasi dan komunikasi, dan lain-lain.

\section{DAFTAR PUSTAKA}

Barbara B. Seels dan Rita C.Richey. 2000. Teknologi Pembelajaran: Definisi dan Kawasannya (Terjemahan Dewi S. Prawiradilaga, Raphael Rahardjo dan Yusufhadi Miarso) Jakarta: Unit Percetakan UNJ

Dabbagh, Nanda dan Brenda BannanRitland.2005. Online Learning: Concept, Strategies, and Application. New Jersey: Pearson Education Inc.

Ely, Donald P.1990. The Diffusion and Impementation of Educational Technology in Developing Nations. New York: ERIC Clearinghouse on Information Resources.

Khan, Badrul.2005. Managing E-lerning Strategies: Design, Delivery, Implementation and Evaluation. USA: Idea Group Inc.
Miarso, Yusufhadi.2005. Menyemai Benih Teknologi Pendidikan. Jakarta: Kencana Media

Molenda, Michael dan Alan Januszewski. 2008. Educational Technology (A Definition with Commentary), New York: Lawrence Erlbaum Associates

Rogers, Evert M. 2000.Diffusion of Innovation (5th ed), New York: The Free Press.

http:/ / www.oktopusz.hu/domain9/files/ modules/module15/2584862F837D BB7.pdf tentang "E-learning, Online Learning, Web-based Learning, or Distance Learning: Unveiling the Ambiguity in Current Terminology", diunduh 05 Februari 2013.

http://www.ncbi.nlm.nih.gov/pmc/articl es/PMC1125774/ tentang "Web based learning", diunduh $05 \mathrm{Fe}$ bruari 2013.

http://www.southalabama.edu/coe/bset/ surry/papers/adoption/chap.htm, Adoption, Diffusion, Implementation, and Institutionalization of Educational Technology, diunduh 05 Februari 2013. 